\title{
ХАРАКТЕРИСТИКА ДОДАТКОВИХ ПІДСТАВ ПРИПИНЕННЯ ОКРЕМИХ ДЕРЖАВНО-СЛУЖБОВИХ ПРАВОВІДНОСИН
}

Стець О. М.

Cтаття присвячена дослідженню сутнісних ознак додаткових підстав припинення окремих державно-службових правовідносин. Установлено, що державно-службові правовідносини, які пов'язані з проходженням державної служби державними службовцями, що обіймають посаду категорії «A», можуть бути припинені внаслідок застосування додаткових підстав за ініціативою суб'єкта призначення. Звернуто увагу на те, що фактичне застосування додаткових підстав припинення окремих державно-службових правовідносин впливає на проходження державноі служби іншими особами, подекуди спричиняючи нормативно дозволену можливість їх звільнення.

Зазначено, що застосування додаткових підстав припинення державної служби нормативно є можливим виключно за ініціативою суб'єкта призначення та стосовно державних службовців, які займають визначену категорію посад державної служби.

Досліджено, що механізм припинення окремих державно-службових правовідносин внаслідок застосування додаткових підстав, крім іншого, характеризується специфікою: а) фактичних причин застосування; б) порядком реалізаціі; в) правового статусу державного службовця, щодо якого його застосовано. Акцентовано на тому, що з моменту прийняття рішення про звільнення державного службовця, який обіймає посаду категорії «A», 3 посади внаслідок застосування додаткових підстав державно-службові правовідносини щодо проходження державної служби не припиняються. Звільнений із посади державний службовець є учасником державно-службових правовідносин протягом наступних шести місяців, у межах яких його може бути переведено без проведення конкурсу на будь-яку вакантну посаду державної служби не нижче категорії «Б» у державних органах, юрисдикція яких поширюється на всю територію України.

Установлено, що набуття державним службовцем статусу «зарахованого за штат» означає якісну зміну: службових обов'язків у межах, визначених керівником державного органу; прав державного службовця в частині набуття можливості обіймати посаду державної служби в спрощеному порядку; системи гарантій шляхом додаткового забезпечення оплати праці.

Ключові слова: державно-службові правовідносини, припинення, додаткова підстава, суб'єкт при-

(c) Стець О. М., 2020 значення, державний службовець, посада державної служби категорії «A».

Stets O. M. Characteristics of additional grounds for termination of certain public service legal relations

The article is devoted to the study of the essential features of additional grounds for termination of certain public service legal relations. It is established that public service legal relations, which are associated with the public service by public servants holding a position of " $A$ " may be terminated due to the use of additional grounds at the initiative of the subject of appointment. Attention is paid to the fact that the actual application of additional grounds for termination of certain public service legal relations affects the conduct of public service by other persons, sometimes causing a legally permitted possibility of their dismissal.

It is noted that the application of additional grounds for termination of public service is legally possible only at the initiative of the subject of appointment and in respect of public servants who hold a certain category of public service positions.

It is determined that the mechanism of termination of certain public service legal relations due to the use of additional grounds, among other things, is characterized by the specifics of: a) the actual reasons for use; b) the order of implementation; c) the legal status of the public servant to whom it is applied. Emphasis is placed on the fact that from the moment of the decision to dismiss a public servant who holds a position of category " $A$ " from office due to the application of additional grounds, public service relations for public service are not terminated. A dismissed public servant is a participant in a public service legal relations for the next six months, within which he may be transferred without a competition to any vacant public service position not lower than category " $B$ " in public bodies whose jurisdiction extends to the whole territory of Ukraine.

It has been established that the acquisition by a public servant of the status of "enrolled in the state" means a qualitative change: of official duties within the limits set by the head of the state body; granted rights in terms of the possibility of holding a public service position in a simplified manner; guarantee systems by providing additional remuneration.

Key words: public service legal relations, termination, additional grounds, subject of appointment, public servant, public service position of category " $A$ ". 
Постановка проблеми та її актуальність. Припинення державно-службових правовідносин відбувається на підставі визначених Законом України «Про державну службу» юридичних фактів. Водночас нормативно виокремлено як загальні підстави припинення державної служби за ініціативою суб'єкта призначення, так і додаткові. За своїми якісно-змістовними ознаками додаткові підстави припинення державної служби можуть бути застосовані виключно до тих державно-службових правовідносин, учасниками яких $\epsilon$ державні службовці, що обіймають посаду категорії «А». Питання застосування положень ст. $87^{1}$ Закону України «Про державну службу» $\epsilon$ невіддільним елементом характеристики проходження державної служби, яким опосередковано визначення специфіки припинення державно-службових правовідносин. Проблематика проходження державної служби $\epsilon$ актуальною тому, що відбиває зміст службового права, водночас вона була й залишається дотепер надзвичайно актуальною, особливо з огляду на докорінні зміни, які відбуваються у всіх сферах суспільного життя, та насамперед у сфері державно-службових відносин.

Аналіз останніх досліджень і публікацій. Суттєвий науковий внесок у розробку концептуальних засад припинення державно-службових правовідносин зроблено такими вченими, як В.Б. Авер'янов, О.Ф. Андрійко, Д.Н Бахрах, Ю.П. Битяк, Л.Р. Біла-Тіунова, С.В. Ківалов, Т.О. Коломоєць та інші. Водночас окреслення сутності додаткових підстав припинення державно-службових правовідносин і процедури їх застосування залишається не розв'язаним 3 урахуванням нормотворчого реформування засад функціонування публічної влади. Крім того, відсутність нормативної деталізації положень щодо застосування додаткових підстав і часткова їх невідповідність міжнародним стандартам свідчить про актуальність обраної теми дослідження.

Метою статті $\epsilon$ дослідження сутнісних ознак додаткових підстав припинення окремих державно-службових правовідносин.

Виклад основного матеріалу. Формулювання назви ст. $87^{1}$ Закону України «Про державну службу» - «Додаткові підстави припинення державної служби окремих державних службовців за ініціативою суб'єкта призначення» [1] - первинно обмежує можливість іï застосування. Видається доцільним зазначити, що законодавство про державну службу було доповнено означеною нормою на підставі Закону України «Про внесення змін до деяких законів України щодо перезавантаження влади» [2] з метою спрощення порядку звільнення з державної служби й підвищення відповідальності державних службовців за досягнення результатів їх діяльності з одночасним відновленням суспільної довіри до державної влади [3].

Застосування додаткових підстав припинення державної служби нормативно $\epsilon$ можливим виключно: 1) за ініціативою суб'єкта призначення; 2) стосовно державних службовців, які займають визначену категорію посад державної служби.

Перша умова означає, що припинення державної служби відповідно до ст. $87^{1}$ Закону України «Про державну службу» являє собою одностороннє волевиявлення суб'єкта призначення, за якого згода іншої сторони (тобто державного службовця) $\epsilon$ непотрібною [4, с. 492]. Усталеним $\epsilon$ визначення суб'єкта призначення на державну службу як державного органу або посадової особи - керівника державної служби, який як учасник державно-службових правовідносин розв'язує питання щодо: прийняття на державну службу, проходження державної служби, припинення державної служби тощо.

Щодо можливості застосування вказаної норми стосовно державних службовців, які займають визначену категорію посад державної служби, то йдеться про таке. Загалом, поняття «категорія посади» відбиває єдину визначально-кваліфікаційну характеристику державної посади, наприклад, спосіб вступу на державну службу; рівень професійно-кваліфікаційні вимоги до претендента на їі заміщення; перелік обмежень під час вступу на державну службу й під час проходження державної служби; право на відставку як підставу припинення службових відносин; соціальне й матеріальне забезпечення [5]. Не виключенням $\epsilon$ використання поняття «категорії посади державної служби» для конкретизації суб'єктного складу державно-службових правовідносин, які можуть бути припинені за наявності додаткових підстав. Відповідно, ст. $87^{1}$ Закону України «Про державну службу» може бути застосовано лише до тих державних службовців, що обіймають посаду державної служби категорії «А» - вищого корпусу державної служби, до якої належать посади: керівника Апарату Верховної Ради України та його заступників; керівника апарату (секретаріату) постійного допоміжного органу, утвореного Президентом України; державного секретаря Кабінету Міністрів України (далі - КМУ) та його заступників, державних секретарів міністерств; керівників центральних органів виконавчої влади, які не $\epsilon$ членами КМУ, та їх заступників; керівників секретаріату 
Конституційного Суду України (далі - КСУ), апаратів Верховного Суду України (далі - ВСУ), вищих спеціалізованих судів та їх заступників; голів місцевих державних адміністрацій; керівників державної служби в інших державних органах, юрисдикція яких поширюється на всю територію України [1].

Таким чином, державно-службові правовідносини, які пов'язані з проходженням державної служби державними службовцями, що обіймають посаду категорії «А», можуть бути припинені внаслідок застосування додаткових підстав за ініціативою суб'єкта призначення. Фактичне застосування додаткових підстав припинення окремих державно-службових правовідносин впливає на проходження державної служби іншими особами, подекуди спричиняє нормативно дозволену можливість їх звільнення. Наприклад, ч. 6 ст. 11 Закону України «Про центральні органи виконавчої влади» встановлено, що звільнення міністра не може бути підставою для звільнення державних службовців і працівників апарату міністерства, крім випадків, передбачених ст. 871 Закону України «Про державну службу». Аналогічна норма міститься в ч. 5 ст. 20 вказаного закону щодо звільнення з посад державних службовців апарату центрального органу виконавчої влади [6].

Механізм припинення державно-службових правовідносин, які пов'язані 3 проходженням державної служби внаслідок застосування додаткових підстав, крім іншого, характеризується специфікою: а) фактичних причин застосування; б) порядком реалізації; в) правового статусу державного службовця, щодо якого його застосовано.

Щодо фактичних причин застосування положень ст. $87^{1}$ Закону України «Про державну службу», то нормативно їх не встановлено, що порушує міжнародні стандарти діяльності публічних службовців. Зокрема, положення Рекомендації № R (2006 рік) 6 Комітету Міністрів Ради Європи державам - членам Ради Європи «Про статус публічних службовців в Європі», якими передбачено, що припинення найму державного службовця повинне здійснюватися у випадках і з причин, визначених законом. Якщо ж причини й підстави звільнення працівника не чіткі, то звільнення працівника виглядає свавіллям керівника й порушує права працівника [7]. Означене $\epsilon$ підставою для оскарження в судовому порядку рішення про звільнення з державної служби. Прикладом може слугувати справа про незаконне звільнення голови Державної податкової служби України й поновлення його на посаді, що розгляда- лася окружним адміністративним судом м. Києва [8]. Доцільним вбачається виокремлення причин, за наявності яких можуть бути застосовані додаткові підстави припинення державної служби. Водночас слід враховувати, що фактичні підстави застосування ст. $87^{1}$ Закону України «Про державну службу» можуть збігатися з підставами, які встановлені ст. 87. Натомість можуть нівелюватись такі умови, як попередження про звільнення та прийняття рішення про припинення державної служби в п'ятиденний строк із дня настання або встановлення відповідного факту [1].

Порядок реалізації механізму припинення окремих державно-службових правовідносин унаслідок застосування додаткових підстав характеризується сукупністю спеціальних ознак. Насамперед можна констатувати недостатність правого регулювання розглядуваного механізму, який частково врегульований лише Законом України «Про державну службу». Натомість первинна стадія припинення державної служби - встановлення фактичних підстав для застосування положень ст. $87^{1}$ - відбувається на підставі застосування адміністративного розсуду. Відповідно, суб'єкт призначення приймає рішення про припинення державної служби державного службовця категорії «А»: 1) з власної ініціативи; 2) на підставі подання Прем'єр-міністра України; 3) на підставі подання, внесеного відповідним міністром; 4) на підставі подання, внесеного відповідним керівником центрального органу виконавчої влади (керівника державного органу). Водночас подання може бути внесено лише протягом встановленого терміну - чотирьох місяців із дня призначення.

Таким чином, суб'єкт призначення та суб'єкти, які уповноважені на подання про звільнення державного службовця, застосовують дискреційні повноваження. Слід виходити з того, що під час реалізації дискреційних повноважень вказані суб'єкти публічної адміністрації зобов'язані суворо дотримуватися законодавства України, діяти виключно відповідно до формули правового регулювання «заборонено все, крім того, що прямо дозволено законом», що знайшло своє відбиття в ст. 6 Конституції України [9]. Можливість суб'єкта призначення застосувати ст. $87^{1}$ Закону України «Про державну службу» пов'язано з його функціональним призначенням. Наприклад, якщо до основних завдань Кабінету Міністрів України віднесено вжиття заходів щодо забезпечення прав і свобод людини й громадянина, створення сприятливих умов для вільного й всебічного розвитку особистості, то Кабінет Міністрів України може 
виконувати це завдання через реалізацію повноважень, якими його уповноважено у сфері правової політики, законності, забезпечення прав і свобод людини й громадянина. Проте перелік цих повноважень конкретно не визначений (вжиття заходів щодо захисту прав і свобод, гідності, життя та здоров'я людини й громадянина від протиправних посягань, охорони власності й громадського порядку, забезпечення пожежної безпеки, боротьби зі злочинністю, запобігання та протидії корупції, здійснення заходів щодо забезпечення виконання судових рішень органами виконавчої влади та їх керівниками тощо [10]), а тому Кабінет Міністрів України відповідно до закону й у межах повноважень, які йому надано, в тому числі як суб'єктові призначення може застосовувати дискреційні повноваження під час обрання необхідних інструментів публічного адміністрування для врегулювання конкретно визначених державно-службових правовідносин із конкретно визначеним їх складом, включаючи звільнення державного службовця.

3 моменту прийняття рішення про звільнення державного службовця, який обіймає посаду категорії «А», внаслідок застосування додаткових підстав державно-службові правовідносини щодо проходження ним державної служби не припиняються. Звільнений із посади державний службовець $\epsilon$ учасником державно-службових правовідносин протягом наступних шести місяців, у межах яких його може бути переведено без проведення конкурсу на будь-яку вакантну посаду державної служби не нижче категорії «Б» у державних органах, юрисдикція яких поширюється на всю територію України [1].

Як наслідок, державний службовець, до якого було застосовано положення ст. $87^{1}$ Закону України «Про державну службу», по закінченню шестимісячного терміну: а) займає запропоновану Національним агентством із питань державної служби посаду державної служби; б) припиняє проходження державної служби й втрачає статус державного службовця.

Цікавою видається зміна структури правового статусу державного службовця, якого звільнено 3 посади внаслідок застосування додаткових підстав. Відповідно, під час звільнення з посади категорії «А» державний службовець набуває правового положення «зарахованого за штат». Водночас галузевого спеціального статусу державного службовця, яким детерміновано наявність визначених прав та обов'язків, особа не втрачає. Набуття статусу «зарахованого за штат» означає, що державний службовець припиняє виконувати службові обов'язки, які встановлені для посади, з якої його звільнено. Одночасно на державного службовця можуть бути покладені обов'язки, перелік яких визначається керівником державного органу. У роз'ясненнях Національного агентства України з питань державної служби зазначено, що у випадку невиконання наданих обов'язків державним службовцем і недотримання ним вимог законодавства про державну службу в період, коли державним службовцем набуто статусу «зарахованого за штат», його може бути притягнуто до дисциплінарної відповідальності [11]. Також зарахований поза штат державний службовець набуває спеціального права щодо можливості зайняття посади державної служби в спрощеному порядку його може бути переведено на будь-яку вакантну посаду державної служби не нижче категорії «Б» у державних органах, юрисдикція яких поширюється на всю територію України [1].

Окремо слід вказати на набуття додаткових гарантій щодо оплати праці й невикористаної відпустки державним службовцем, якого було звільнено з посади відповідно до ст. $87^{1}$ Закону України «Про державну службу» [12], що виражено в такому: 1) оплата праці здійснюється за фактично відпрацьований час: посадового окладу за останньою займаною посадою; надбавки за вислугу років (3 відсотки посадового окладу державного службовця за кожний календарний рік стажу державної служби, але не більше 50 відсотків посадового окладу); надбавки за ранг державного службовця; 2) під час звільнення з державної служби по закінченню шестимісячного терміну проводиться нарахування заробітної плати й місяці звільнення за фактично відпрацьований час; 3) у випадку надання щорічної основної оплачуваної відпустки виплачується середня заробітна плата й грошова допомога [13].

Підсумовуючи, доходимо висновку, що наявність нормативно визначених додаткових підстав припинення державно-службових відносин щодо проходження державної служби дозволяє в спрощеному порядку звільнити державних службовців із посад категорії «А» на підставі застосування дискреційних повноважень суб'єкта призначення. Зазначене може мати як позитивний ефект унаслідок оперативного усунення від посад осіб, які об'єктивно не можуть продовжувати виконання покладених на них обов'язків через невідповідність їх поведінки чи репутації етико-правовим нормам, так і негативний, що опосередковано порушенням прав таких осіб через нечіткість 
законодавства, яким врегульовано процедуру застосування додаткових підстав припинення державної служби. Важливість і широке коло суспільних відносин, у межах яких здійснюється проходження державної служби, й розвиток елементів механізму їх правового регулювання опосередковують потребу здійснення подальших досліджень цієї проблематики.

\section{Література}

1. Про державну службу : Закон України від 10 грудня 2015 р. № 889-VIII (дата оновлення: 01 січня 2021 р.) / Верховна Рада України. URL: https: / /zakon.rada.gov.ua/laws/show/889-19\#Text (дата звернення: 05.01.2021).

2. Про внесення змін до деяких законів України щодо перезавантаження влади : Закон України від 19 вересня 2019 р. № 117-IX (дата оновлення: 01 лютого 2020 р.) / Верховна Рада України. URL: https: //zakon.rada.gov.ua/laws/show/117-20\#n437 (дата звернення: 05.01.2021).

3. Пояснювальна записка до проєкту Закону України «Про внесення змін до деяких законів України щодо перезавантаження влади» від 29 серпня 2019 р. / Верховна Рада України. URL: http:// w1.c1.rada.gov.ua/pls/zweb2/webproc4_2?pf3516= $1066 \& s k l=10$ (дата звернення: 17.01.2021).

4. Біла-Тіунова Л.Р. Державна служба України. Загальна частина : навчальний посібник. Одеса, 2020. 511 c.

5. Адміністративне право України. Повний курс : підручник / за ред. В.В. Галунька, О.М. Правоторової. Видання третє. Київ : Академія адміністративно-правових наук, 2020. 466 с.

6. Про центральні органи виконавчої влади : Закон України від 17 березня 2011 р. № 3166-VI (дата оновлення: 15 січня 2021 р.) / Верховна Рада України. URL: https://zakon.rada.gov.ua/laws/ show/3166-17\#Text (дата звернення: 17.01.2021).

7. Публічна служба. Зарубіжний досвід та пропозиції для України / За заг. ред. В.П. Тимощука, А.М. Школика. Київ : Конус-Ю, 2007. 735 с.

8. Ухвала окружного адміністративного суду м. Києва про прийняття позовної заяви до розгляду та відкриття провадження у справі № 640/10063/20.
Єдиний судовий реєстр судових рішень. URL: https: / / reyestr.court.gov.ua/Review/89159780\# (дата звернення: 17.01.2021).

9. Конституція України : Закон України від 28 червня 1996 р. № 254к/96-ВР (зі змінами, внесеними Законом України від 08 грудня 2004 р. № 2222-IV) / Верховна Рада України. URL: http://zakon2.rada.gov.ua/ laws/show/254\%D0\%BA/96-\%D0\%B2\%D1\%80 (дата звернення: 15.01.2021).

10. Про Кабінет Міністрів України : Закон України від 27 лютого2014 р. № 794-VII / Верховна Рада України. URL: https://zakon.rada.gov.ua/laws/ show/794-18\#Text (дата звернення: 15.01.2021).

11. Щодо реалізації положень ч. 2 ст. $87^{1}$ Закону України «Про державну службу» : роз'яснення Національного агентства України з питань державної служби від 10 червня 2020 р. URL: https://nads.gov.ua/ storage/app/uploads/public/5ee/1da/0a3/5ee1da0a39 cfe867799244.pdf (дата звернення: 17.01.2021).

12. Щодо припинення державної служби окремих державних службовців, які перебувають поза штатом держаного органу після завершення визначеного граничного строку : роз'яснення Національного агентства України з питань державної служби від 31 березня 2020 р. URL: https:// nads.gov.ua/npas/shchodo-pripinennya-derzhavnoyisluzhbi-okremih-derzhavnih-sluzhbovciv-yakiperebuvayut-poza-shtatom-derzhanogo-organupislyazavershennya-viznachenogo-granichnogo-stroku. (дата звернення: 17.01.2021).

13. Про затвердження умов оплати праці державних службовців категорії «А», зарахованих за штат державного орган : Постанова Кабінету Міністрів України від 27 листопада 2019 р. № 977 / Кабінет Міністрів України. URL: https://zakon.rada.gov.ua/ laws/show/977-2019-\%D0\%BF\#n8 (дата звернення: 15.01.2021).

Cтець O. М., кандидат юридичних наук, завідувач кафедри конституційного, міжнародного та приватного права Криворізького факультету Національного університету «Одеська юридична академія» 